\title{
In vitro cultivation and acclimatization of Miltonia flavescens (Lindl.) Lindl. with ora- pro-nobis extract (Pereskia aculeata Mill.)
}

Cultivo in vitro e aclimatização de Miltonia flavescens (Lindll.) Lindll. com extrato de ora-pro-nóbis

(Pereskia aculeata Mill.)

Cultivo in vitro y aclimatizatión de Miltonia flavescens (Lindl.) Lindl. com extracto de ora-pro-nobis

(Pereskia aculeata Mill.)

Received: 04/13/2021 | Reviewed: 04/20/2021 | Accept: 04/26/2021 | Published: 05/10/2021

\author{
Samara Zanella \\ ORCID: https://orcid.org/0000-0001-8961-3628 \\ State University of Western Paraná, Brazil \\ E-mail: samara_zanella@hotmail.com \\ Suzana Stefanello \\ ORCID: https://orcid.org/0000-0001-7744-0192 \\ Federal University of Paraná, Brazil \\ E-mail: sstefanello@ufpr.br \\ Paulo Vanderlei Sanches \\ ORCID: https://orcid.org/0000-0003-2159-9115 \\ State University of Western Paraná, Brazil \\ E-mail: pvsanches@yahoo.com.br
}

\begin{abstract}
The aim of this study was to evaluate the effect of aqueous ora-pro-nobis (Pereskia aculeata Mill.) extract on in vitro growth, survival rate, and acclimatization of Miltonia flavescens. Crude ora-pro-nobis extract was produced by infusing $10 \mathrm{~g}$ of dry leaves fractionated in $100 \mathrm{~mL}$ of distilled water. The treatments consisted of the crude extract (100\%) and dilutions of $75 \%, 50 \%$, and $25 \%$ added to Murashige and Skoog $1 / 2$ culture medium (control treatment: absence of extract) where seedlings germinated in vitro were cultivated. After 270 days of cultivation, growth data were collected, and the plants acclimated. The survival rate was evaluated every 30 days, and the growth of the aerial part and root system were measured after 120 days of acclimatization. The data were submitted to analysis of variance and a test of the separation of means (Skott-Knott). For the number of leaves, the $100 \%$ treatment had the highest average value, differing statistically from the other treatments. For the length of the root system and fresh mass, the highest averages occurred in the control and $100 \%$ treatments. For the number of roots and shoots, there were no differences between treatments. After 120 days of acclimatization, plants from the $100 \%$ treatment had the lowest survival percentage, and plants from the $25 \%$ and $50 \%$ treatments had the greatest increase in the growth of the aerial part and root systems, demonstrating these treatments would be beneficial for the cultivation of this species.
\end{abstract}

Keywords: Orchidaceae; Micropropagation; Culture media; Biostimulant activity.

\section{Resumo}

O objetivo deste estudo foi avaliar o efeito de concentrações de extrato aquoso de ora-pro-nóbis (Pereskia aculeata Mill.) no crescimento in vitro, sobrevivência e aclimatização de Miltonia flavescens. O extrato bruto foi obtido através da infusão de $10 \mathrm{~g}$ de folhas secas fracionadas em $100 \mathrm{~mL}$ de água destilada. Os tratamentos consistiram do extrato bruto (100\%) e diluído a $75 \%, 50 \%$ e $25 \%$ acrescido ao meio de cultura MS 1/2 (controle: ausência de extrato) onde plântulas germinadas in vitro foram cultivadas. Após 270 dias de cultivo, dados de crescimento foram coletados e as plantas aclimatizadas. A cada 30 dias avaliou-se a taxa de sobrevivência e aos 120 dias o crescimento da parte aérea e sistema radicular. Os resultados foram submetidos a análise de variância e teste de Skott-Knott. Para o número de folhas, o tratamento com $100 \%$ de extrato apresentou o maior valor médio, diferindo estatisticamente dos demais tratamentos. Para o comprimento do sistema radicular e massa fresca, as maiores médias ocorreram no controle e com $100 \%$ de extrato. Para o número de raízes e número de brotos, não houve diferença entre os tratamentos. Após 120 dias de aclimatização, as plantas provenientes do tratamento $100 \%$ apresentaram a menor percentagem de sobrevivência e as plantas oriundas dos tratamentos com $25 \%$ e $50 \%$, apresentaram maior incremento na parte aérea e raízes, demonstrando que estes tratamentos podem ser benéficos a longo prazo para o cultivo da espécie.

Palavras-chave: Orchidaceae; Micropropagação; Meios de cultivo; Atividade bioestimulante. 


\section{Resumen}

El objetivo de este estudio fue evaluar el efecto de preferencia del extracto acuoso de ora-pro-nobis (Pereskia aculeata Mill.) sobre el crecimiento in vitro, áreas y aclimatación de Miltonia flavescens. El extracto crudo se añadió infundiendo $10 \mathrm{~g}$ de hojas secas fraccionadas en $100 \mathrm{ml}$ de agua destilada. Los tratamientos consistieron en el extracto crudo (100\%) y diluido al $75 \%, 50 \%$ y $25 \%$ agregado al medio de cultivo MS 1/2 (control: ausencia de extracto) donde se cultivaron plántulas germinadas in vitro. Después de 270 días de cultivo, se recopilaron datos de crecimiento y las plantas se aclimataron. Se evaluó la tasa de supervivencia cada 30 días y el crecimiento de la parte aérea y sistema radicular a los 120 días. Los resultados obtenidos fueron sometidos a análisis de varianza y prueba de separación de medias (Skott-Knott). Para el número de hojas, el tratamiento con 100\% de extracto presentó el valor promedio más alto, difiriendo estadísticamente de los demás tratamientos. Para la longitud del sistema radicular y el peso fresco, los promedios más altos se presentaron sin control y con $100 \%$ de extracto. Para el número de raíces y número de brotes, no hubo diferencia entre tratamientos. Después de 120 días de aclimatación, las plantas del tratamiento al $100 \%$ mostraron el menor porcentaje de supervivencia y las plantas de los tratamientos con $25 \%$ y 50\%, mostraron un mayor incremento en la parte aérea y raíces, demostrando que estos tratamientos pueden ser beneficiosos a largo plazo por el cultivo de la especie.

Palabras clave: Orchidaceae; Micropropagação; Meios de cultivo; Atividade bioestimulante.

\section{Introduction}

The family Orchidaceae is one of the most diverse families in species number, and has great economic and ecological importance. The dynamics and maintenance of the balance of an ecosystem are highly dependent on various life forms, and orchids perform fundamental ecological functions, mainly related to pollination and the maintenance of complex ecological chains (Duarte \& Gandolfi, 2013).

However, many orchid species are threatened due to deforestation and predatory collection in their natural habitats, making it essential to utilize techniques for mitigating this problem. One of these is in vitro cultivation that allows a high germination percentage in a short period, thus contributing to the conservation of native or threatened species (Juras et al., 2019).

Miltonia flavescens (Lindl.) Lindl. is a native orchid species of the Atlantic Forest, found mainly in the south and southeast regions of Brazil, and is threatened due to habitat fragmentation and predatory collection. Thus, it is necessary to use alternative forms of production, such as in vitro propagation techniques, which allow the production of plants on a large scale, ensuring their conservation and reintroduction into the natural environment (Lemes et al., 2020). During in vitro cultivation, a culture medium containing the required nutrients for plant development is used, which offers fixation support (Faria et al., 2012). The culture medium can include substances that aim to optimize plant growth, such as growth regulators or plant extracts.

Plant extracts act as biostimulants and are obtained from natural materials. Several studies have reported the beneficial effect of these substances on plant development (Amatuzzi et al., 2020; Yakhin et al., 2017). Besides enriching the culture medium with vitamins, minerals, and other molecules, plant extracts can be of great value for micropropagation. These culture media represent a natural alternative to the use of growth regulators, enriching the culture media and making them cheaper (Amatuzzi et al., 2020); thus decreasing production costs.

There are reports of the biostimulant effect of supplementing the growth medium with plant extracts, with beneficial results on in vitro germination and growth (Setiari et al., 2016), plant survival (Amatuzzi et al., 2020), and shoot and leaf formation during orchid acclimatization (Charoenwattana \& Petprapai, 2013).

The ora-pro-nobis (Pereskia aculeata Mill.) is a plant of the family Cactaceae found throughout the Brazilian territory. It is a perennial, shrubby species and the only genus in the family that produces true leaves. It has long branches, and the older stems are endowed with eminent spines, whereas the younger branches have aculeles (Madeira et al., 2016).

The plant has recently become popular because of its nutritional value, with high protein content. In addition, it produces a considerable amount of minerals such as potassium, magnesium, zinc, and especially calcium and iron (Madeira et 
al., 2016), and antioxidant compounds (Sousa et al., 2014) that might decrease with the cooking of the leaves (Souza et al., 2021).

Because of its composition, aqueous extracts obtained from ora-pro-nobis leaves can positively influence the growth of other plants; however, there are no studies of its use in the in vitro cultivation of orchids. Previous studies with ora-pronobis leaf extract were undertaken by Silva et al. (2017) and Ceretta (2018) and tested on lettuce plants. The ethanolic extract did not affect seed germination or mitotic index (Silva et al., 2017), and the aqueous extract (5\%) obtained by decoction and sprayed on seedlings showed a beneficial effect on the formation of the aerial part and root system in trials conducted in a greenhouse (Ceretta, 2018).

The period after in vitro cultivation, in which the plants move to the ex vitro environment (acclimatization), is one of the most important and critical steps in the success of the propagation protocol. Thus, positive acclimatization results depend on the environmental adjustment of the plants that, before being definitively introduced into the ex vitro environment, must be acclimatized gradually to withstand the changes and survive under natural conditions (Alves, 2018).

Thus, the aim of the present study was to evaluate the effect of different concentrations of aqueous ora-pro-nobis $(P$. aculeata) extract on the in vitro growth, survival rate, and acclimatization of $M$. flavescens, aimed at future reintroduction programs in the natural environment.

\section{Methodology}

The experiments were conducted at the laboratories of the Plant Anatomy and Morphology and Applied Mycology and Medicinal Plants at the Federal University of Paraná (UFPR), Setor Palotina, Palotina, PR, from August 2019 to June 2020.

\subsection{Obtaining M. flavescens seedlings}

The M. flavescens seedlings used in the experiment were obtained from cross-pollinated seeds and in vitro germination, at approximately 6 months of age, $0.5 \mathrm{~cm}$ in length, and an average of three leaves and one root. Germination and initial cultivation of these seedlings occurred in Murashige and Skoog (MS) basal culture medium with half the concentration of macronutrients and micronutrients (MS 1/2) plus sucrose (30 g.L $\mathrm{L}^{-1}$ ) (Murashige \& Skoog, 1962) and solidified with Dinamica ${ }^{\circledR}$ bacteriological agar $\left(7\right.$ g. $\left.\mathrm{L}^{-1}\right)$. Plants were grown in a growth room at $24^{\circ} \mathrm{C}$ and $16 \mathrm{~h}$ photoperiod with a light intensity of $40 \mu \mathrm{mol} \mathrm{m}^{-2} \mathrm{~s}^{-1}$.

\subsection{Aqueous extract from ora-pro-nobis (P. aculeata)}

The aqueous extract of ora-pro-nobis was obtained from the leaves of plants grown in the Garden of Medicinal and Aromatic Plants of UFPR, Setor Palotina, and collected in July 2019. After collection, the leaves were washed with tap water and then with distilled water. They were then subjected to drying in an oven with forced air circulation at $45^{\circ} \mathrm{C}$ for 6 days.

The crude aqueous extract was obtained by infusing the leaves (pouring boiling water over the fragmented leaves in small portions for $15 \mathrm{~min}$ ) at a concentration of $10 \mathrm{~g}$ of dry mass in $100 \mathrm{~mL}$ of distilled water. The extract was filtered using filter paper, after which the debris was discarded and the liquid part was reserved. From the crude extract obtained (100\%), dilutions were made using distilled water in the proportions of $75 \%, 50 \%$, and $25 \%$, following the methodology described by Ceretta (2018) and Amatuzzi (2018). 


\subsection{Treatments and growing conditions}

The treatments consisted of the crude ora-pro-nobis extract (100\%) and dilutions made with the distilled water at $75 \%, 50 \%$, and $25 \%$ added to MS $1 / 2$ culture medium. A control was included, which contained the medium without the extract. Sucrose ( $\left.30 \mathrm{~g} . \mathrm{L}^{-1}\right)$ was added to the culture medium and the $\mathrm{pH}$ was adjusted to 5.8 after the addition of the aqueous extract, and then solidified with Dinamica ${ }^{\circledR}$ bacteriological agar $\left(7 \mathrm{~g} . \mathrm{L}^{-1}\right)$. The culture medium was sterilized in an autoclave at $121^{\circ} \mathrm{C}$ for $20 \mathrm{~min}$. M. flavescens plants were placed in the flasks (Figure 1) in a laminar flow chamber.

Figure 1. Flasks with culture medium containing Miltonia flavescens plants in the different treatments with aqueous extract of Pereskia aculeata.

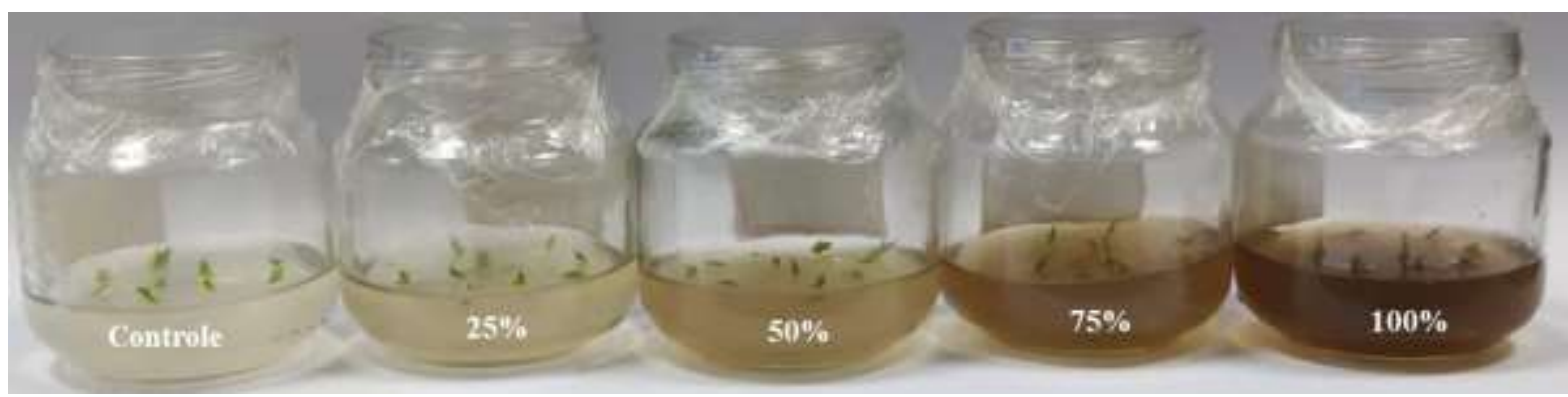

Source: Authors.

The design was entirely randomized and the experimental unit consisted of one glass flask containing 10 plants and seven repetitions. Cultivation occurred in a growth room with an average temperature of $24 \pm 2^{\circ} \mathrm{C}$, photoperiod of $16 \mathrm{~h}$ with a light intensity of $40 \mu \mathrm{mol} \mathrm{m} \mathrm{m}^{-2} \mathrm{~s}^{-1}$ supplied by two white fluorescent lamps of $40 \mathrm{~W}$ each.

Subcultivation was performed every 90 days and, after 270 days, the growth variable data of all the plants in the experimental units were collected and analyzed. The following variables were evaluated: number of leaves, roots, and shoots; height of the aerial part and length of the root system $(\mathrm{cm})$ (measured with a ruler); and fresh mass $(\mathrm{g})$ (measured with an analytical balance).

\subsection{Acclimatization}

The acclimatization monitoring of $M$. flavescens occurred in Toledo, PR, at coordinates $28^{\circ} 05^{\prime} 56^{\prime \prime} \mathrm{S}$ and $48^{\circ} 40^{\prime} 30^{\prime \prime}$ $\mathrm{W}$, indoors under natural light and protected from the sun, at room temperature from June to October 2020. The plants at approximately $3 \mathrm{~cm}$ in height cultivated in vitro were removed from the flasks, washed under running water to remove the culture medium adhered to the roots, and measured for the height of the aerial part and length of the root system for later comparison with the initial and final values.

A total of 24 plants from each in vitro treatment with ora-pro-nobis extract (control, 25\%, 50\%, 75\%, and 100\%) were placed in polystyrene trays with holes at the base for drainage, with one plant per tray unit $\left(12.25 \mathrm{~cm}^{2}\right.$ and height of $\left.5.5 \mathrm{~cm}\right)$, filled with moss substrate, and covered with transparent plastic to maintain humidity.

A total of 15 days after the start of the experiment, the plants received foliar fertilization from a hand sprayer containing $1.0 \mathrm{~mL} . \mathrm{L}^{-1}$ of NPK $10-10-10$, plus the following micronutrients: $0.1 \%$ iron, $0.1 \%$ zinc, $0.1 \%$ copper, $0.3 \%$ sulfur, and $0.5 \%$ manganese. After 30 days, the plastic cover was removed.

The plant survival percentage was evaluated every 30 days and after 120 days of acclimatization the plants were removed from the substrate and evaluated for the height of the aerial part and length of the root system. The difference between the final and initial values of each variable was calculated using the expression $\mathrm{R}=(\mathrm{VF}-\mathrm{VI})$, where $\mathrm{VF}$ is the value of 
the variable after acclimatization and VI is the value of the variable before acclimatization. The surviving plants in good condition were transferred to a phorophyte attached to a trunk to evaluate the survival and effectiveness of in vitro cultivation for repopulation and recovery purposes of endangered species.

\subsection{Statistical analysis}

The data from the in vitro cultivation with the different extract concentrations and acclimatization were submitted to analysis of variance, and a test of the separation of means (Skott-Knott) at $5 \%$ significance using the $\mathrm{R}$ environment in the RStudio interface, version 4.0.2, was performed.

\section{Results and Discussion}

\subsection{Effect of extract on growth}

After 270 days of $M$. flavescens in vitro cultivation, the greatest increase in the number of leaves occurred in the $100 \%$ treatment (ora-pro-nobis leaf extract), which was statistically different from the other treatments. For the height of the aerial part, the highest average was obtained in the control treatment (absence of extract), which was statistically different from the other treatments (Table 1).

For the root system length and fresh mass variables, the highest averages occurred in the absence of extract and 100\% treatments (Table 1). There were no significant differences between the means of the treatments and the different extract concentrations for the number of roots and shoots variables.

Table 1. Mean values for the number of leaves (NL), number of roots (NR), number of shoots (NS), aerial part height (APH), root system length (RSL), and fresh mass (FM) for plants of Miltonia flavescens cultivated in culture medium supplemented with different concentrations. of aqueous extract of ora-pro-nobis (Pereskia aculeata), after 270 days of cultivation.

\begin{tabular}{ccccc}
\hline Extract $(\boldsymbol{\%})$ & NL & $\begin{array}{c}\text { APH } \\
(\mathbf{c m})\end{array}$ & $\begin{array}{c}\text { RSL } \\
(\mathbf{c m})\end{array}$ & $\begin{array}{c}\text { FM } \\
(\mathbf{g})\end{array}$ \\
\hline Control & $7.6 \mathrm{~b}$ & $3.2 \mathrm{a}$ & $2.4 \mathrm{a}$ & $95.4 \mathrm{a}$ \\
$\mathbf{2 5}$ & $6.4 \mathrm{c}$ & $2.2 \mathrm{~b}$ & $1.8 \mathrm{~b}$ & $57.0 \mathrm{~b}$ \\
$\mathbf{5 0}$ & $6.9 \mathrm{c}$ & $1.9 \mathrm{~b}$ & $1.6 \mathrm{~b}$ & $57.6 \mathrm{~b}$ \\
$\mathbf{7 5}$ & $7.4 \mathrm{~b}$ & $2.2 \mathrm{~b}$ & $1.8 \mathrm{~b}$ & $60.0 \mathrm{~b}$ \\
$\mathbf{1 0 0}$ & $8.2 \mathrm{a}$ & $2.5 \mathrm{~b}$ & $2.2 \mathrm{a}$ & $86.7 \mathrm{a}$ \\
\hline $\mathbf{C V}(\boldsymbol{\%})$ & 5.31 & 16.78 & 12.13 & 22.45 \\
\hline
\end{tabular}

*Means followed by different letters in the columns differ by the Scott-Knott test at the 5\% significance level. Source: Authors.

For the number of leaves, greater increments were obtained in the $100 \%$ and $25 \%$ extract treatments. As the extract concentration in the culture medium increased, there was a gradual increase in the number of leaves (Figure 2A). None of the different extract treatments caused a significant increase in the formation of roots, with the highest average for the number of roots obtained in the control treatment (Figure 3B).

Regarding the height of the aerial part (Figure 2B) and length of the root system (Figure 3B), the plants showed similar responses as the extract concentration increased. The highest average for both variables was obtained in the control treatment. The addition of $25 \%$ and $50 \%$ of extract in the culture medium caused a decrease in plant height and root length. However, from the $75 \%$ concentration on, an increase in the means of these variables was observed. 
Figure 2. Average number of leaves (A) and aerial part height (B) of Miltonia flavescens plants after 270 days of cultivation on MS 1/2 culture medium with extract (control, 25\%, 50\%, 75\%, and 100\%) of Pereskia aculeata.

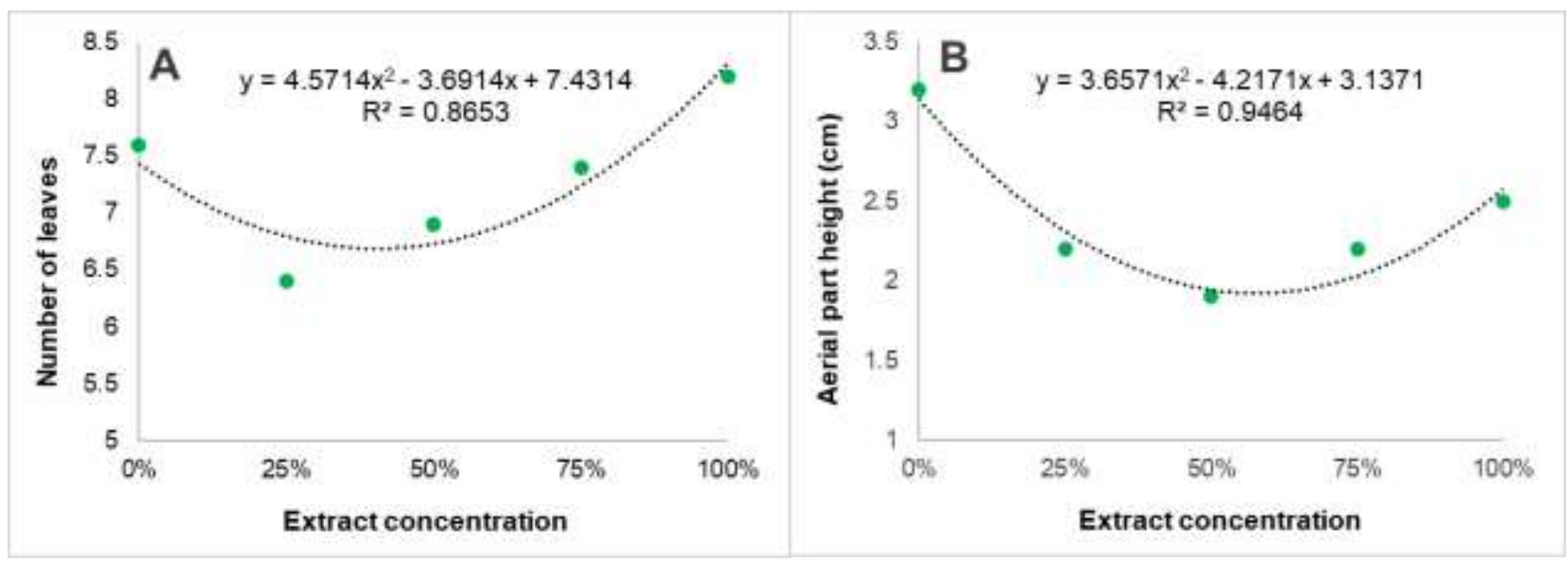

Source: Authors.

Leaves are directly related to photosynthetic activity in plants (Furlani, 2004) and an increase in the number of leaves might contribute to their development in vitro (Amatuzzi et al., 2020) and their survival during the ex vitro period. In a study by Oliveira et al. (2013), in which the mineral composition of ora-pro-nobis leaves was evaluated, high phosphorus, zinc, and magnesium levels were observed. Magnesium has a structural function as it is located in the center of the chlorophyll molecule, and is found in high abundance in the leaves (Furlani, 2004). It might be related to the increase in the number of leaves with increasing concentrations of the extract in the culture medium.

Figure 3. Number of roots (A) and root system length (B) of Miltonia flavescens plants after 270 days of cultivation on MS $1 / 2$ culture medium with extract (control, 25\%, 50\%, 75\%, and 100\%) of Pereskia aculeata.
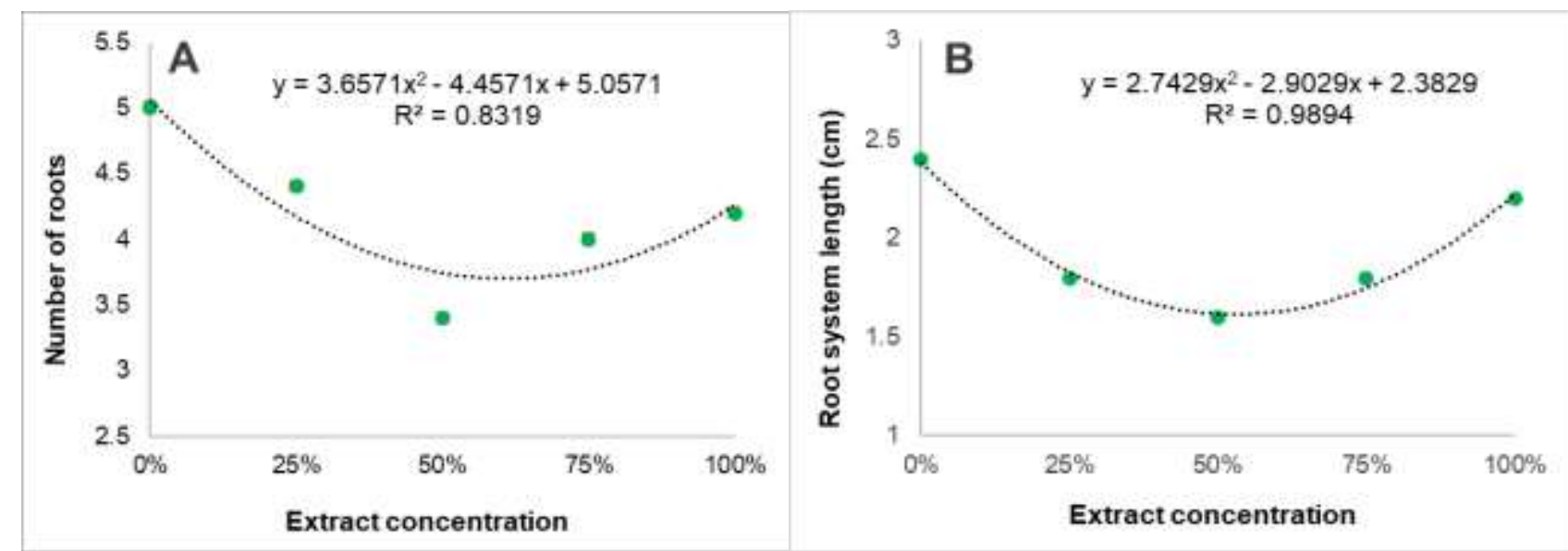

Source: Authors.

Charoenwattana and Petprapai (2013) evaluated the effects of the ethanolic extract of Nelumbo nucifera leaves combined with chitosan during in vitro cultivation of Dendrobium hybrids (Orchidaceae). In this study, the authors found an increase in the number of leaves of the cultivated plants after 4 weeks in the presence of the plant extract, differing significantly from the control treatment, which was similar to the results found in the present study.

Ribeiro (2005), who cultivated orchids of the genus Cattleya in culture medium supplemented with different boron and zinc concentrations, obtained similar results to those found in the present study in the study. This result was related to a 
probable nutritional unbalance caused by nutrients in the culture medium as the concentration of minerals was increased, especially zinc. Ora-pro-nobis plants have high amounts of minerals such as iron, zinc, magnesium, and boron, among others, in their leaves (Madeira et al., 2016; Takeiti et al., 2009), which may have caused such an unbalance, generating the observed result.

Amatuzzi (2018), using in vitro cultivations of Epidendrum secundum (Orchidaceae), demonstrated that the addition of the extract of the alga Ulva fasciata to the culture medium exerted a deleterious effect, inhibiting plant development, with ,the highest extract concentrations presenting smaller sizes in an inversely proportional way. Similarly, increases in the extract concentration in the culture medium caused a decrease in root development. These data corroborate with those found in the present study, where the control was the most effective in the growth of the aerial part and roots, although an increase was also observed in the $100 \%$ extract concentration.

Figure 4. Fresh mass (A) and number of shoots (B) of Miltonia flavescens plants after 270 days of cultivation on MS $1 / 2$ culture medium with extract (control, 25\%, 50\%, 75\%, and 100\%) of Pereskia aculeata.

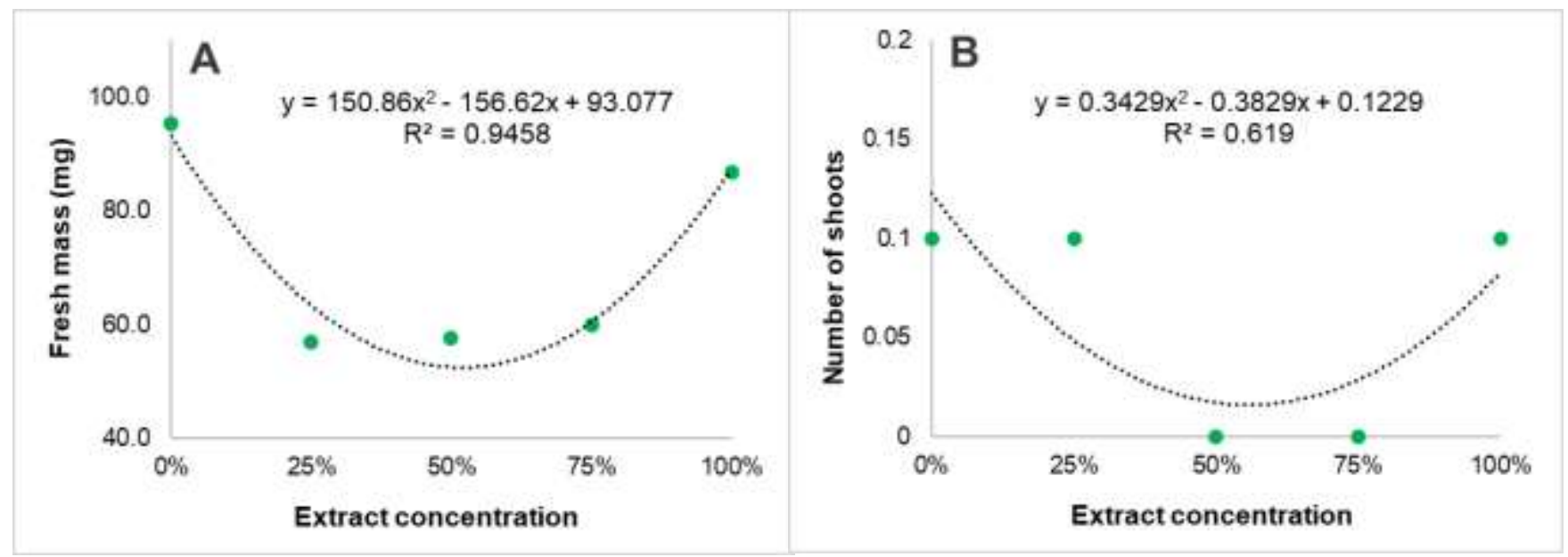

Source: Authors.

Similarly, the result for the fresh mass of the plants (Figure 4A) showed a drastic loss of mass in the $25 \%, 50 \%$, and 75\% treatments compared to the control, where the highest average mass was obtained, followed by an increase in the fresh mass in the $100 \%$ treatment. Similar results were described in a study by Amatuzzi et al. (2020), where E. secundum (Orchidaceae) seedlings, submitted to treatments with higher concentrations of algal extract $\left(100 \mathrm{mg} . \mathrm{L}^{-1}\right)$, had a lower fresh mass than the average mass obtained for the same variable in the absence of the extract.

The increase in mass in the $100 \%$ treatment in the present study indicates that the mineral elements present in the plant extract of $P$. aculeata interacted with the macro and micronutrients in the culture medium. For the number of shoots (Figure 4B), a small increase was observed near the highest extract concentration; however, there was no significant difference regarding the other treatments.

Studies of orchid in vitro cultivation using other extracts of plant origin, such as coconut water, have shown an efficient effect of this extract in promoting in vitro growth because it contains considerable amounts of myo-inositol, cytokinins, nucleotides, and other organic compounds, which act directly on the development of plants in vitro (Silva et al., 2016). However, ora-pro-nobis leaves are composed mainly of mineral elements, e.g., calcium, iron, potassium, magnesium, zinc, phosphorus, boron, and manganese, and have high protein content (Oliveira et al., 2013; Takeiti et al., 2009). These substances might be beneficial for supplementing the medium; however, unlike coconut water, they cannot produce 
morphogenesis on their own without the presence of phytoregulators, similar to what was described in the study by Franco and Echart-Almeida (1998) using potato extract.

\subsection{Acclimatization}

After 30 days of acclimatization, plants from all treatments showed 100\% survival (Table 2), demonstrating that maintaining the plants in an environment with a cover to preserve humidity during the first month of acclimatization, which is one of the most critical times, was advantageous. High survival rates showed that cultivation with P. aculeata extract had no deleterious effect on the plants during this initial acclimatization period.

High percentage of survival was also obtained at 60 and 90 days of acclimatization, except for those grown in the $100 \%$ extract after 90 days of acclimatization, which showed a decrease in the survival percentage, differing significantly from the other treatments (Table 2). These plants (cultivated with 100\% extract) were the ones with the highest number of leaves during the in vitro cultivation phase. Leaves in plants are the organs through which transpiration occurs (Taiz et al., 2017); therefore, a hypothesis is that a greater number of leaves in plants subjected to this treatment would cause a consequent increase in the transpiration rate, contributing to greater water stress in these plants.

Table 2. Percent survival of Miltonia flavescens plants from different treatments with Pereskia aculeata extracts during acclimatization.

\begin{tabular}{ccccc}
\hline \multirow{2}{*}{$\begin{array}{c}\text { Extract } \\
(\%)\end{array}$} & 30 days & $\mathbf{6 0}$ days & $\mathbf{9 0}$ days & $\mathbf{1 2 0}$ days \\
\cline { 2 - 5 } & $100 \mathrm{a}$ & $96 \mathrm{a}$ & $92 \mathrm{a}$ & $54 \mathrm{a}$ \\
Control & $100 \mathrm{a}$ & $100 \mathrm{a}$ & $100 \mathrm{a}$ & $25 \mathrm{a}$ \\
$\mathbf{2 5}$ & $100 \mathrm{a}$ & $100 \mathrm{a}$ & $87 \mathrm{a}$ & $29 \mathrm{a}$ \\
$\mathbf{5 0}$ & $100 \mathrm{a}$ & $96 \mathrm{a}$ & $96 \mathrm{a}$ & $54 \mathrm{a}$ \\
$\mathbf{7 5}$ & $100 \mathrm{a}$ & $96 \mathrm{a}$ & $58 \mathrm{~b}$ & $20 \mathrm{a}$ \\
$\mathbf{1 0 0}$ & 0 & 6.63 & 11.66 & 66.34 \\
\hline CV $(\%)$ & &
\end{tabular}

*Means followed by different letters in the columns differed by the Scott-Knott test at the 5\% significance level. Source: Authors.

In the study by Dorneles and Trevelin (2011), Cattleya intermedia Lindl. orchid plants acclimated for 90 days with sphagnum moss as the substrate showed 53\% survival. For the species Sophronitis cernua Lindl. and Brassavola flagellaris Barb. Rodr. acclimated and grown in substrate composed of a mixture of coconut fiber and sphagnum moss, the survival percentages were between $60 \%$ and $80 \%$ at 30 days and between $30 \%$ and $50 \%$ at 120 days (Ichinose, 2012), corroborating the results found in the present study.

After 120 days of acclimatization, the plants had a decrease in survival, which was attributed to an increase in the ambient temperature and decrease in the air humidity because the plants were not cultivated in a controlled temperature environment. For seedlings of the same species as that of the present study, Stefanello, et al. (2009) found similar results after 60 days of acclimatization, with a sharp drop in the survival rate, recording survival between 5\% and 30\% after 90 days of acclimatization of plants grown on different substrates.

The sharp drop in the survival rate of plants after 30- and 60-days acclimatization can be attributed to the removal of the plastic covering of the trays combined with hydric stress on the plants due to low relative humidity (Stefanello et al., 2009). Colombo et al. (2005) showed that the form of irrigation during this period also influenced survival, describing the low survival rate of seedlings of the hybrid Cattleya guttata Lindl $\times$ Laelia tenebrosa Lindl. (Orchidaceae) submitted to manual 
irrigation. According to the authors, the ideal irrigation system was an automatic system providing intermittent, homogeneous, and constant irrigation.

Lemes (2015) studied the acclimatization of M. flavescens in substrate composed of sphagnum moss and coconut fiber, and evaluated the effects of intermediate acclimatization of plants. The author obtained positive results and high survival rates in plants submitted to pre-acclimatization for 30 days in a growth room with controlled and homogeneous temperature, photoperiod, and radiation, validating that the maintenance of plants in a place without major variations in environmental conditions is a determining factor for the success of acclimatization.

High mortality rates during the ex vitro period can be explained by the numerous morphological, anatomical, and physiological changes that the plants suffer when they are removed from the in vitro environment, where they present reduced size and leaf area, and non-functional stomata, among other factors (Bandeira et al., 2007). Such factors can directly influence the ability of the plants to survive adverse conditions or environmental and water stresses.

Growth rates, obtained from the ratio between the final and initial sizes of the plants during the recorded acclimatization period, are shown in Table 3. Despite a high plant mortality rate, especially after 90 days, the plants that survived showed an increase in the formation of the aerial part and root systems (Figure 5).

Table 3. Mean size ratio (growth rate) for the aerial part height (APH) and root system length (RSL) from the averages of the plants for these variables before acclimatization and after 120 days of acclimatization in the moss type substrate.

\begin{tabular}{ccc}
\hline \multirow{2}{*}{ Extract $(\%)$} & APH $(\mathbf{c m})$ & $\mathbf{R S L}(\mathbf{c m})$ \\
\cline { 2 - 3 } & 0.32 & 0.38 \\
Control & 0.54 & 0.38 \\
$\mathbf{2 5}$ & 0.48 & 0.72 \\
$\mathbf{5 0}$ & 0.28 & 0.20 \\
$\mathbf{7 5}$ & 0.32 & 0.22 \\
$\mathbf{1 0 0}$ & *not significant (n=5). \\
& Source: Authors.
\end{tabular}

Therefore, despite the lower growth of the aerial part and root system during the in vitro period in the 25\% and 50\% treatments, the plants in these treatments obtained the greatest increments in these growth variables when cultivated ex vitro for 120 days. This demonstrates that at these concentrations, the beneficial effect of the extract may be greater in the long term. The addition of the crude extract was advantageous because it allowed for greater plant growth due to the mineral supplementation that the plants received during this period. Because these are plants with a slow metabolism and development, the acclimatization process also demands a long period to present positive results in terms of growth of plants of this species (Faria et al., 2012). 
Figure 5. Appearance of Miltonia flavescens plants grown in different concentrations of the aqueous extract of ora-pronobis after 120 days of acclimatization.

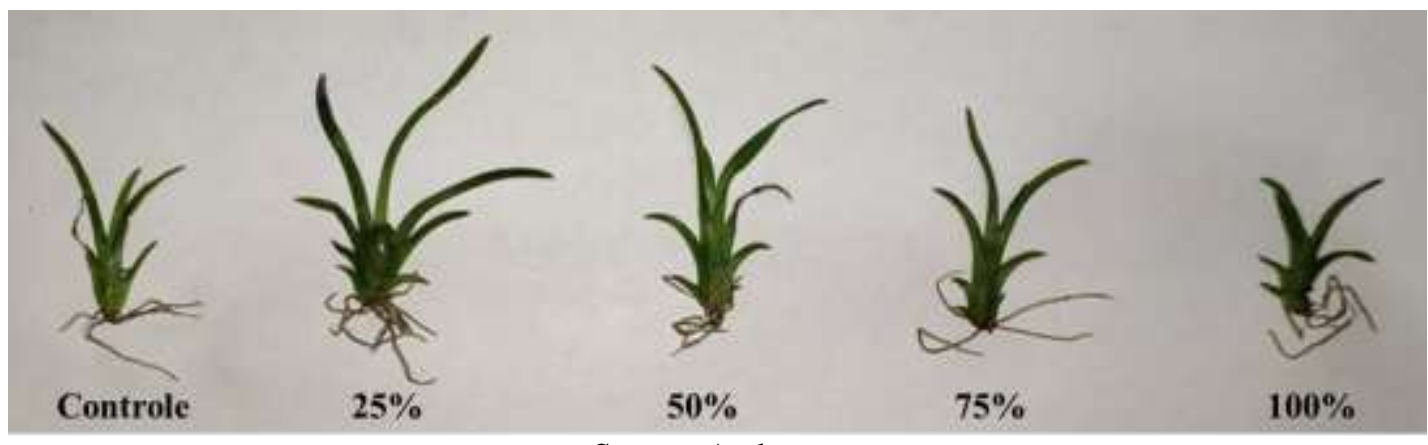

Source: Authors.

Sousa et al. (2015) cultivated Brassavola tuberculata with auxin and acclimatized this species in sphagnum moss, coconut fiber, and combined substrates, and found that the overall average increment of growth variables was positive. After 210 days of acclimatization, despite a considerable mortality rate in some treatments, in all the treatments there was an increase in the height of the aerial part and length of the root system during the acclimatization stage, which was similar to that seen in the present study.

The transfer of plants that survived acclimatization to the phorophytes was not quantitatively evaluated; however, it showed that the M. flavescens plants germinated and propagated in vitro grew well and were likely to be reintroduced into natural environments (Figure 6).

Figure 6. Surviving plants of Miltonia flavescens attached to the phorophyte.

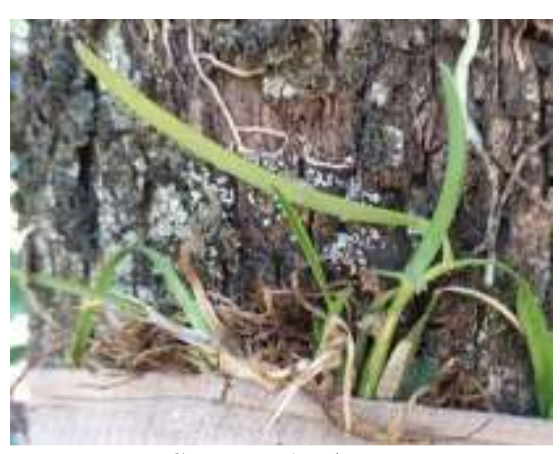

Source: Authors.

\section{Conclusion}

The aqueous extract of ora-pro-nobis ( $P$. aculeata Mill.) did not significantly affect most variables during the in vitro growth of M. flavescens (Lindl.) Lindl. During the in vitro cultivation period, the $100 \%$ treatment was considered advantageous for increasing the number of leaves. However, this high concentration proved to be inefficient over the long term in the survival and growth of the plants after the in vitro period.

After 120 days of acclimatization plants from the $25 \%$ and $50 \%$ treatments had the greatest increase in the growth of the aerial part and root systems, demonstrating these treatments would be beneficial for the cultivation of this species. Further studies and monitoring are required because the literature is still scarce regarding the reintroduction processes of threatened species cultivated in vitro, with the adaptation of plants to phorophytes being one of the main obstacles of the process. 


\section{References}

Alves, L. R. (2018). Análise da propagação e desenvolvimento inicial in vitro e aclimatização de Brassavola martiana Lindl (Orchidaceae). 46 p. (Dissertação de Mestrado). Programa de Pós-graduação em Biodiversidade, Ecologia e Conservação, Universidade Federal do Tocantins.

Amatuzzi, J. C. A. de. (2018). Efeito de extratos de algas marinhas na morfogênese in vitro de Epidendrum secundum Jacq. 52 p. (Dissertação de Mestrado). Programa de Pós-Graduação em Botânica, Universidade Federal do Paraná.

Amatuzzi, J. C. de. A., Vieira, L. do. N., Sant'anna-Santos, B. F., Noseda, M. D., \& Fraga, H. P. de. F. (2020). Improved in vitro development of Epidendrum secundum (Orchidaceae) by using aqueous extract of the seaweed Kappaphycus alvarezii (Rhodophyta, Solieriaceae). Acta Physiologiae Plantarum, 42(136), 1-9. https://doi.org/10.1007/s11738-020-03129-6

Bandeira, F. S., Xavier, A., Otoni, W. C., \& Lani, E. R. G. (2007). Aclimatização ex vitro de plantas propagadas pela enxertia in vitro de clones de Eucalyptus utophylla X E. grandis. Revista Árvore, 31(5), 773-781. https://doi.org/10.1590/S0100-67622007000500001

Ceretta, J. M. (2018). Efeito do extrato aquoso de ora-pro-nóbis (Pereskia aculeata Miller) na germinação e desenvolvimento de alface. (Trabalho de Conclusão de Curso). 34f. Graduação em Agronomia - Universidade Federal do Paraná, Palotina, PR, Brasil.

Charoenwattana, P., \& Petprapai, U. (2013). Effect of chitosan and lotus extracts as growth promoter in Dendrobium orchid. International Journal of Environmental and Rural Development, Pathum Thani, 4(2), 133-137. http://iserd.net/ijerd42/42022.pdf

Colombo, L. A., Faria, R. T., Assis, A. M., \& Fonseca, I. C. De. B. (2005). Aclimatação de um híbrido de Cattleya em substratos de origem vegetal sob dois sistemas de irrigação. Acta Scientiarum Agronomy, 27(1), 145-150. https://doi.org/10.4025/actasciagron.v27i1.2134

Dorneles, L. T., \& Trevelin, V. (2011). Aclimatação e reintrodução de Cattleya intermedia Graham ex Hook (Orchidaceae) obtidas por propagação in vitro. Iheringia, Série Botânica, 66, 167-174. https://isb.emnuvens.com.br/iheringia/article/view/47

Duarte, M. M., \& Gandolfi, S. (2013). Enriquecimento de florestas em processo de restauração: aspectos de epífitas e forófitos que podem ser considerados. Hoehnea, 40(3), 507-514. https://doi.org/10.1590/S2236-89062013000300010

Faria, R. T. De, Assis, A. M., Unemoto, L. K., \& Carvalho, J. F. R. P. De. (2012). Meios de cultura. In: R. T. De. Faria, A. M. De. Assis, L. K. Unemoto, \& J. F. R. P. De. Carvalho. Produção de orquídeas em laboratório. (Cap. 3, p. 27-42). Londrina: Mecenas.

Faria, R. T. De, Stegani, V., Bertoncelli, D. J., Alves, G. A. C., \& Assis, A. M. De. (2018). Substrates for the cultivation of epiphytic orchids. Semina: Ciências Agrarias, 39(6), 2851-2866. http://dx.doi.org/10.5433/1679-0359.2018v39n6p2851

Franco, E. T. H., \& Echart-Almeida, C. (1998). Ação de extratos vegetais e fitorreguladores na organogênese de Begonia rex. Ciência e Natura, 20(20), 131142. https://periodicos.ufsm.br/cienciaenatura/article/view/26964/pdf

Furlani, A. M. C. (2004). Nutrição mineral. In: G. B. Kerbauy, Fisiologia vegetal. (Cap. 2, p. 40-75) Guanabara Koogan.

Ichinose, J. G. S. (2012). Paclobutrazol no crescimento e desenvolvimento in vitro e na aclimatização de Sophronitis cernua Lindl. e Brassavola flagellaris Barb. Rodr. (Orchidaceae). 79 p. (Tese de Doutorado). Programa de Pós-Graduação em Agronomia - Universidade Estadual Paulista Júlio de Mesquita Filho, Jaboticabal, SP, Brasil.

Juras, M. C R., Jorge, J., Pescador, R., Ferreira, W. M. De, Tamaki, V., \& Suzuki, R. M. (2019). In vitro culture and acclimatization of Cattleya xanthina (Orchidaceae), an endangered orchid of the Brazilian Atlantic Rainforest. Rodriguésia, 70, 1-11. https://doi.org/10.1590/2175-7860201970014.

Lemes, C. S. R. (2015). Germinação, desenvolvimento e aclimatização de Miltonia flavescens Lindl. (Orchidaceae). 66 p. (Tese de Doutorado). Programa de Pós-Graduação em Agronomia - Universidade Federal da Grande Dourados, Dourados, MS, Brasil.

Lemes, C. S. R., Sorgato, J. C., Soares, J. S., Nunes, D. P., \& Ribeiro, L. M. (2020). Initial in vitro establishment of the Native Cerrado Orchid Miltonia flavescens. Floresta e Ambiente, 27(4), 1-7. http://dx.doi.org/10.1590/2179-8087.022118

Madeira, N. R, Amaro, G. B, Melo, R. A. De C. e., Botrel, N, \& Rochinski, E. (2016). Cultivo de ora-pro-nóbis (Pereskia) em plantio adensado sob manejo de colheitas sucessivas. Brasília, DF: Embrapa, 20 p. https://www.embrapa.br/busca-de-publicacoes/-/publicacao/1066888/cultivo-de-ora-pro-nobis-pereskia-emplantio-adensado-sob-manejo-de-colheitas-sucessivas

Murashige, T., \& Skoog, F. (1962). A revised medium for rapid growth and bioassays with tobacco tissue cultures. Physiologia Plantarum, 15 , $495-497$. https://doi.org/10.1111/j.1399-3054.1962.tb08052.x

Oliveira, D. De C. Da S., Wobeto, C., Zanuzo, M. R., \& Severgnini, C. (2013). Composição mineral e teor de ácido ascórbico nas folhas de quatro espécies olerícolas não-convencionais. Horticultura Brasileira, 31(3), 472-475. http://dx.doi.org/10.1590/S0102-05362013000300021

Ribeiro, L. de S. (2005). Adequação de meio de cultura para crescimento in vitro de orquídeas do gênero Cattleya. 69 p. (Tese de Doutorado). Programa de Pós-Graduação em Agronomia/Fisiologia Vegetal - Universidade Federal de Lavras.

Setiari, N., Purwantoro, A., Moeljopawiro, S., \& Semiarti, E. (2016). Peptone and tomato extract induced early stage of embryo development of Dendrobium phalaenopsis Orchid. Journal of Tropical Biodiversity and Biotechnology, 1(2), 77-86.

Silva, D. O., Seifert, M., Nora, F. R., Bobrowski, V. L., Freitag, R. A., Kucera, H. R., Nora, L., \& Gaikwad, N. W. (2017). Acute toxicity and cytotoxicity of Pereskia aculeata, a highly nutritious Cactaceae plant. Journal of Medicinal Food, 20(4), 403-409. https://doi.org/10.1089/jmf.2016.0133

Silva, H. F. J., Asmar, S. A., Oliveira, R. C., Luz, J. M. Q., \& Melo, B. (2016). Alternative supplements and MS medium concentrations in the in vitro establishment of Dipteryx alata. Bioscience Journal, 32(5), 1138-1146. https://doi.org/ 10.14393/BJ-v32n5a2016-33682 
Research, Society and Development, v. 10, n. 5, e39710515032, 2021

(CC BY 4.0) | ISSN 2525-3409 | DOI: http://dx.doi.org/10.33448/rsd-v10i5.15032

Soares, J. S. (2018). Técnicas de cultivo in vitro como alternativa para a conservação de Schomburgkia crispa Lindl. (Orchidaceae) e sua reintrodução em ambiente natural. 101 p. (Tese de Doutorado). Programa de Pós-Graduação em Recursos Naturais - Universidade Estadual do Mato Grosso do Sul, MS, Dourados.

Sousa, R. M. F., Lira, C. S., Rodrigues, A. O., Morais, S. A. L., Queiroz, C. R. A. A., Chang, R., Aquino, F. J., Muñoz, R. A. A., \& Oliveira, A. (2014). Atividade antioxidante de extratos de folhas de ora-pro-nóbis (Pereskia aculeata Mill.) usando métodos espectrofotométricos e voltamétricos in vitro. Bioscience Journal, 1(1), 318-323. http://200.19.146.79/index.php/biosciencejournal/article/view/19618

Sousa, G. G., Rosa, Y. B. C. J., Macedo, M. C., \& Soares, J. S. (2015). Aclimatização de Brassavola tuberculata com a utilização de ANA em diferentes substratos. Horticultura Brasileira, 33(2), 208-215. https://doi.org/10.1590/S0102-053620150000200012

Souza, A. H. de, Silva, B. M., Silva, E. C. da., Augusti, R., Melo, J. O. F., \& Carlos, L. de A. (2021) Influence of thermal processing on the characteristics and chemical profile of ora-pro-nobis by PS/MS paper spray. Research, Society and Development, 10(2), 1-17. https://doi.org/10.33448/rsd-v10i2.12119

Stefanello, S., Silveira, E. V., Oliveira, L. K., Besson, J. C. F., \& Dutra, G. M. V. (2009). Eficiência de substratos na aclimatização de plantas de Miltonia flavescens Lindl. propagadas in vitro. Revista em Agronegócio e Meio Ambiente, 2(3), 467-476. https://doi.org/10.17765/2176-9168.2009v2n3p467-476

Taiz, L., Zeiger, E., Moller, I., \& Murphy, A. (2017). Balanço hídrico das plantas. In: L. Taiz, E. Zeiger, I. Moller, A. Murphy. Fisiologia e desenvolvimento vegetal. (Cap. 4, 110-116. 6.ed.). Porto Alegre: Artmed.

Takeiti, C. Y., Antonio, G. C., Motta, E. M. P., Collares-Queiroz, F. P., \& Park, K. J. (2009). Nutritive evaluation of non-conventional leafy vegetable (Pereskia aculeata Miller). International Journal of Food Sciences and Nutrition, 60(1), 148 -160. https://doi.org/10.1080/09637480802534509

Yakhin, O. I., Lubyanov, A. A., Yakhin, I. A., \& Brown, P. H. (2017). Biostimulants in plant science: a global perspective. Frontiers in Plant Science, 7(2049), 1-32. https://doi.org/10.3389/fpls.2016.02049 